Open Access

\title{
The effect of externalities on adoption of social customer relationship management (SCRM)
}

Vicky Gu', Jonathan Davis ${ }^{2^{*}}$, Ray Cao $^{2}$ and John Vogt ${ }^{2}$

\author{
* Correspondence: davisg@uhd.edu \\ ${ }^{2}$ The University of Houston \\ Downtown, One Main Street, \\ Houston, TX 77002, USA \\ Full list of author information is \\ available at the end of the article
}

\begin{abstract}
The rise of social media technology has led to new customer relationship management tools that engage customers more easily and directly (social customer relationship management, SCRM). However, the usefulness of SCRM is contingent upon a successful adoption by an organization. Various technology adoption theoretical frameworks have been proposed for social media technologies generally, and for SCRM specifically. This paper extends the literature by exploring network externalities as a potential driver of SCRM adoption in organizations by surveying 363 supply chain professionals regarding their behaviors and uses of SCRM. The results suggest that network externalities have a substantial effect on adoption of SCRM in business organizations and that a perception of higher network externalities has a positive effect on adoption. This implies that organizations should select SCRM systems with better network externalities and also that they should educate their workforce about those strong network externalities leading up to the adoption.

Keywords: Social CRM, CRM, Technology adoption, Supply chain management
\end{abstract}

\section{Background}

Much has been written about the rising importance of customer relationship management (CRM) in augmenting a company's ability to interact with its customers and potential customers. The application of CRM contributes not only to the acquisition and retention of customers for the company through identification and satisfaction of the customers' needs; it also facilitates the communication between the company and their customers [1]. However, this is a peer-to-peer capability where the company directly interacts with one customer.

The recent emergence and growing popularity of social media has introduced a new element into CRM. By adding the important social media dimension to the existing CRM systems, companies are able to combine the existing knowledge about each prospective and current customer with new information about their social media activities. When the companies or their related products are communicated via LinkedIn, Facebook, or Twitter accounts, companies can track and manage the conversation, respond more quickly and better, and anticipate the customers' or potential customers' needs. This also leads to positive spillover effects through social media pages where

(c) The Author(s). 2017 Open Access This article is distributed under the terms of the Creative Commons Attribution 4.0 International License (http://creativecommons.org/licenses/by/4.0/), which permits unrestricted use, distribution, and reproduction in any medium, provided you give appropriate credit to the original author(s) and the source, provide a link to the Creative Commons license, and indicate if changes were made. 
network members interact $[2,3]$. Thus, social CRM (SCRM) is the use of social media platforms and tools to manage customer relationships.

Due to the newness of SCRM, there is limited research concerning its adoption [4]. This study takes SCRM as its main theme and proposes network externalities as the overarching theory in explaining SCRM adoptions in business organizations. Network externalities theory is the theory that the value of a technology is dependent upon the larger network of users of that technology. Network externality has been defined in economics and business as a change in the benefit, or surplus, that an agent derives from a good or service when the number of other agents consuming the same kind of good or service changes [5]. This applies fittingly to SCRM adoption because the very nature of social media technology is that it allows a user to engage with a network of other users, and so, the value of that social media technology will be impacted by, and perhaps even determined by, its user network. For SCRM, the implication would be that the more firms use the technology, the more valuable it is to each firm, and the more firms will adopt and use it $[6,7]$.

The objective of this study is to investigate network externality as an antecedent that impacts SCRM adoption and also to describe its impact.

Aforementioned, SCRM is a state-of-the-art technology and its adoption is still in its infancy. To the best of our knowledge, this study is the first attempt to explore the SCRM adoption in the SCM context. This study provides both researchers and managers theoretical and empirical evidence that a firm's network externalities in SCRM have a positive effect on its SCRM adoption. From a theoretical perspective, this study endeavors to explore the adoption behavior of SCRM applying network externality theory and empirically test it in a SCM arena. From a managerial standpoint, the findings of the research suggest that practitioners need to examine the interorganizational effects to understand SCRM technology to be well prepared for its implementation.

The next section is a review of the literature for this study. In the "Literature review" section, the research model, as well as the underlying hypotheses, is described. Subsequently, the research method, together with the data analysis results and discussion, is presented. Finally, in the "Discussion and conclusions" and "Limitations and future research" sections, the conclusions, implications, and future research opportunities are discussed.

\section{Literature review}

SCRM

In today's age of mass production and mass marketing, many companies are trying hard to establish and nurture their connections to existing and potential customers by identifying their unique needs and desires, with the aim of increasing long-term customer loyalty [8]. Customer relationship management (CRM) has been widely used to address this urgent need. CRM facilitates customer engagement with marketing, sales, and service for some organizations or has served as a cross-functional, customer-driven business process management strategy for others [9]. CRM initiatives have resulted in improved competitiveness by boosting customer satisfaction and retention rates [10-12].

Over time, new communication technologies have transformed traditional CRM into electronic CRM, mobile CRM, and, more recently, SCRM. 
SCRM has no generally accepted definition, just as CRM has no single definition [13]. There is one popular definition of SCRM as being "a philosophy and a business strategy, supported by a technology platform, business rules, processes and social characteristics, designed to engage the customer in a collaborative conversation in order to provide mutually beneficial value in a trusted and transparent business environment" [14]. As such, it is an integration of customer-facing activities with emergent social media applications in order to engage customers in collaborative conversations and enhance customer relationships $[15,16]$.

Traditional CRM is an organization-controlled process to interact with the customer using technology. This is a peer-to-peer communication and is subject to the guidelines and management of the organization. The CRM strategy is enabled by the organization with processes and technologies and is focused on managing the customer relationship or relationships over their lifetime with the aim of bringing value to the organization and longevity to the relationship, if possible [17]. CRM strategies are often the operational responses of the organization to manage the customer and the relationship.

SCRM is different from this process, as the organization no longer controls the process or the technology. SCRM is subject only to the rules, if any, of the platform upon which the social conversation takes place. The participants include anyone who is interested in the conversation or interaction process [18]. The company needs to find ways to use this process as a strategic initiative to collaborate with the customer or customers [12]. The rise of SCRM leads to a need for new strategies, which aim to facilitate a customer interaction that adds value to the customer.

There is little researched direction on the correct method to integrate social media into the CRM process and management [19]. Many companies have therefore experimented with different media. However, as per the definition, the technology requires collaboration and information sharing, so the greatest value appears to be achieved where these are augmented by appropriate technical resources [20-22]. The resources must be able to give the organization a technical advantage and must bring a competency to the SCRM capability. The competency that is required is not a single functional capability or skill, but a much wider skill which will enable the person to increase the value to the customers and other social media participants by engaging them and collaborating with them to enhance the relationship. This requires multiple parties, trained in using social media, working across the organization's functional areas and hierarchy [17].

SCRM value is therefore firstly in the area of customer collaboration and interaction, but it also requires some value to be added to the customer. This value is not just "belonging" or "being heard", but rather in the areas of "achieving a change in the organization" or "receiving a monetary value" or similar tangible outcomes for interacting. It is notable that there are only a limited number, around 5\% [17], of people who continuously interact on social media sites. The majority beyond this $5 \%$ require added value to feel the need to interact on social media. It requires multi-channel, carefully targeted campaigns with tangible rewards to bring the large majority of the people into the collaboration. These constitute an enormous number of people who, if approached correctly and with a value proposition, will collaborate and offer insight, interaction, and valuable knowledge to the company. SCRM offers companies enormous value in a different manner. In order to collaborate, the staff no longer can be from one functional area 
such as marketing. It will take multiple areas of the business to respond to customer dialogs with timely, accurate, and sensible answers to questions and issues raised [17]. This means a trained task force from all parts of the company is now required to satisfy the customer and achieve collaboration. The knowledge of the customer is fed back into multiple parts of the organization concurrently and is of great value $[16,17]$.

The outcome of this is increased trust and greater insight into customers' needs, which leads to improved customer retention and loyalty. SCRM can also be a way to engage customer communities for the purpose of testing ideas, products, and service offerings [3, 23-29]. Used strategically, it brings customers to participate with the company delivering value to them, and, in the process, it allows the company to establish communication, improve customer loyalty, and gain insights. It is a rich tool for bringing and binding customers to the firm.

\section{Technology adoption}

In adoption literature, the particular technologies under study play a role in determining which theories are used to explain their progression. For example, if the innovation is mainly technical, then a technology-organization-environment (TOE) theoretical framework applies [30]. The TOE framework is effective when the technology mainly concerns protocols and standards in the technology itself [31] and other theories use a similar basis, such as diffusion of innovation (DOI) theory [32].

Other frameworks are interested in the work itself and whether a tool innovation (technology) applies neatly to the tasks involved. Task characteristics, technological characteristics, and task-technology fit (TTF) theory is one such framework [33]. TTF assumes a goal-oriented adopter and positions the technology under consideration as a means to an end for a worker needing to complete a task and that it is this dynamic that drives adoption.

Still, other frameworks apply in circumstances where the technology is intended to establish its efficacy through a network effect. The network externalities theoretical framework is such a theory, and it posits that the value of such a technological innovation depends on network effects, and so, adoption will be driven by the size and applicability of the network of users of that technology. The classic example of network externalities at work is the telephone. A person's demand for a telephone is dependent on there being a second person who also has a telephone, and preferably someone the first person might walk to talk with. The larger the network of other telephone users, the more desirable owning a telephone becomes, because its utility, or value, increases commensurately $[6,34]$.

This effect has previously been documented as driving adoption of technologies such as home computers [35], electronic payments [36], and mobile phones [37]. Moreover, network externalities theory has been used to explain adoption and growth of social media platforms [38-40] as well as showing a significant role in the adoption of traditional customer relationship management (CRM) systems [41].

Rising interest in SCRM has led to investigations of its adoption in organizations. Recently, studies have explored the effects of technological, organizational, environmental, and managerial characteristics on SCRM adoption [4, 42-44]. In addition, a few studies have analyzed SCRM adoption by using technological capabilities [27], TOE 
theory, and AHP [45]. TAM model or the diffusion of innovation framework was also applied in some studies $[2,46]$.

This study aims to evaluate SCRM adoption based on the network externality theoretical framework, because it has been demonstrated to have substantial adoption impacts on related technologies, such as social media and CRM [38-40, 47, 48]. The authors of this paper hypothesize that adoption of CRM systems that are enhanced and characterized by social media components will be driven by network externalities. This hypothesis derives from the nature of SCRM and its component social media technologies as fundamentally network-driven and the purpose of SCRM systems as gateways into a network of customers. To the extent that a SCRM technology provides this benefit, it will be desirable, and the benefit will flow from the size, reach, and completeness of the network of customers. Therefore, positive network externalities should drive SCRM adoption. This study contributes to the literature by extending the analysis of SCRM adoption into this realm. Therefore, this paper proposes to examine the effects of network externalities on the adoption of SCRM through analyzing a survey of supply chain professionals designed to assess this question. The reason for selecting supply chain management professionals as the sample of the target for SCRM adoption is due to the value of SCRM to the supply chain management function in the organizations and in-between the organizations. The dependence on systems and technology nowadays is almost a requirement for supply chain management to be competitive and successful with today's larger volumes and global trade.

\section{Research hypotheses and methodology}

Hypotheses

When the value of an innovation depends on the number of other users who adopt that innovation, positive adoption externalities, also known as network effects or network externalities, are said to exist [6,34]. Network effects can be either direct network effects, which are the physical effects of being able to exchange information, or indirect network effects, which arise from the interdependencies with other organizations in the use of complementary goods $[6,34,49]$.

Numerous types of technologies are said to generate network effects, including computer networks for academic research [50], electronic data interchange (EDI) [51], and open-standard interorganizational systems $[31,52,53]$. In each case, the value of being a member of the network of adopters increases with each additional adoption decision. For instance, EDI is highly valuable when every partner in a supply chain adopts. In contrast, if only one firm were to adopt EDI, it only gains a new data format and new standards. In this case, there is no benefit to be gained by exchanging this newly standardized information with partners.

SCRM is an extension of CRM, which is a technology that possesses significant network effects in addition to its stand-alone benefits [54]. CRM, like ERP and other types of interorganizational systems, allows a firm to benefit from both the direct network effects of being able to exchange object information with business partners and the indirect network effects of interdependency with other organizations. SCRM, as an addition to CRM, uses social media services, techniques, and technology to enable organizations to engage directly with customers or potential customers. Rather than managing 
relationships, SCRM aims at facilitating collaborative experiences and dialog that customers value [17]. All of these are direct network effects that arise from sharing information. Similarly, the price of hardware, software applications, and middleware should decline as more companies adopt SCRM, due to economies of scale, competition, and technological development. Furthermore, the ease with which consulting expertise can be accessed should increase. All of these benefits are indirect network effects.

Therefore, the authors hypothesize:

Hypothesis 1: Higher levels of perceived network effects are positively associated with the adoption of social CRM in organizations.

Hypothesis 1A: Higher levels of perceived direct network effects are positively associated with the adoption of social CRM in organizations.

Hypothesis 1B: Higher levels of perceived indirect network effects are positively associated with the adoption of social CRM in organizations.

\section{Methods}

\section{Data collection}

The data for this research was collected via an email survey (i.e., MS Excel format) sent to 363 supply chain professionals during a 1-month time span. The total number of respondents of the survey is 232, while the total number of usable responses is 214 . To make certain that respondents have enough knowledge to answer the survey questionnaire, a background of this study along with a video of SCRM was provided in an introduction to the survey and respondents were asked to read the introductory material and watch a video before completing the survey questionnaire. As a result, the response rate is $60.57 \%$. Table 1 shows the demographic information of the respondents. While $53.27 \%$ of the respondents are from a variety of manufacturing industries, $21.50 \%$ of them are from various service industries. While all respondents are currently MBA students, 31 of them $(14.49 \%)$ already obtained a master's degree in other fields. Also, $41.59 \%$ of the respondents work for small organizations $(\leq 500), 27.10 \%$ work for medium organizations (501 to 10,000), and 31.31\% work for large organizations $(>10,000)$. While $29.44 \%$ of the respondents have managerial responsibilities, $61.68 \%$ do not. Table 1 also shows that $24.30 \%$ of the respondents have stayed more than 5 years in their current position, while $75.70 \%$ of them have been in their current position for less than 5 years.

\section{Questionnaire construction}

The perceived value of a network has been explored in various studies $[55,56]$, and perceptual measures have been developed [31,57], several of which are utilize in this study [58]. Control variables in the study include firm size, industry, and job tenure. Perceptual measures of items (survey questions) are adopted and adapted from Parthasarathy and Bhattacherjee [57].

A pilot study was conducted by distributing a preliminary questionnaire to eight managers of several companies in a major city in the southwestern region of the USA. 
Table 1 Demographic Information

\begin{tabular}{|c|c|c|}
\hline Industry & Number of respondents & Percentage of respondents \\
\hline \multicolumn{3}{|l|}{ Manufacturing } \\
\hline Manufacturing & 37 & $17.29 \%$ \\
\hline Oil and gas & 9 & $4.21 \%$ \\
\hline Subtotal & 46 & $21.50 \%$ \\
\hline \multicolumn{3}{|l|}{ Service } \\
\hline Communication & 4 & $1.87 \%$ \\
\hline Construction & 4 & $1.87 \%$ \\
\hline Education & 13 & $6.07 \%$ \\
\hline Financial services & 25 & $11.68 \%$ \\
\hline Government & 2 & $0.93 \%$ \\
\hline Healthcare & 5 & $2.34 \%$ \\
\hline Real estate & 21 & $9.81 \%$ \\
\hline Services & 26 & $12.15 \%$ \\
\hline Supply chain management & 14 & $6.54 \%$ \\
\hline Subtotal & 114 & $53.27 \%$ \\
\hline Other & 54 & $25.23 \%$ \\
\hline Total & 214 & $100 \%$ \\
\hline \multicolumn{3}{|l|}{ Company size (employee no.) } \\
\hline \multicolumn{3}{|l|}{ Small organization } \\
\hline Less than 50 & 53 & $24.77 \%$ \\
\hline $51-100$ & 9 & $4.21 \%$ \\
\hline $101-500$ & 27 & $12.62 \%$ \\
\hline Subtotal & 89 & $41.59 \%$ \\
\hline \multicolumn{3}{|l|}{ Medium organization } \\
\hline $501-1000$ & 14 & $6.54 \%$ \\
\hline $1001-10,000$ & 44 & $20.56 \%$ \\
\hline Subtotal & 58 & $27.10 \%$ \\
\hline \multicolumn{3}{|l|}{ Large organization } \\
\hline $10,000-50,000$ & 31 & $14.49 \%$ \\
\hline Greater than 50,000 & 36 & $16.82 \%$ \\
\hline Subtotal & 67 & $31.31 \%$ \\
\hline \multicolumn{3}{|l|}{ Job position } \\
\hline Employee & 132 & $61.68 \%$ \\
\hline Manager & 63 & $29.44 \%$ \\
\hline Full-time student & 2 & $0.93 \%$ \\
\hline Intern & 3 & $1.40 \%$ \\
\hline Other & 14 & $6.54 \%$ \\
\hline \multicolumn{3}{|l|}{ Job tenure } \\
\hline \multicolumn{3}{|l|}{ Job tenure $\leq 5$ years } \\
\hline Less than 1 year & 46 & $21.50 \%$ \\
\hline $1-5$ years & 116 & $54.21 \%$ \\
\hline Subtotal & 162 & $75.70 \%$ \\
\hline \multicolumn{3}{|l|}{ Job tenure $>5$ years } \\
\hline $6-10$ years & 31 & $14.49 \%$ \\
\hline
\end{tabular}


Table 1 Demographic Information (Continued)

\begin{tabular}{cll}
\hline Industry & Number of respondents & Percentage of respondents \\
\hline $11-15$ years & 16 & $7.48 \%$ \\
$16-20$ years & 3 & $1.40 \%$ \\
$20+$ years & 2 & $0.93 \%$ \\
Subtotal & 52 & $24.30 \%$ \\
\hline
\end{tabular}

Managers were asked to examine the degree to which the preliminary questionnaire captured the constructs and how easy or difficult the preliminary questionnaire was to complete. Based upon results from the preliminary questionnaire, a revised questionnaire was constructed and used to gather responses from the respondents.

Surveys were administered in 2017, where intent to adopt was measured as a categorical dependent variable on a 7-point Likert scale.

\section{Data preparation}

In this research, all of the items have the absolute values of skewness index below 1.0 while the absolute values of kurtosis are fewer than 10; thus, they meet the rule for the normality test of both skewness and kurtosis (see Table 2). The Pearson correlation in Table 3 shows that direct network effect, indirect network effect, and SCRM adoption are positively related. Each of these three correlations is significant; however, none of these three correlations is more than 0.9 . Therefore, the dataset shows no singularity issue. Sampling adequacy was measured using both the Kaiser-Meyer-Olkin (KMO) measure of sampling adequacy and Bartlett's test of sphericity. According to the rule of thumb, the value of KMO should be greater than 0.5, while Bartlett's test ought to be significant, if the sample is deemed to be adequate. Table 4 shows that the value of $\mathrm{KMO}$ is 0.840 and Bartlett's test is significant at a level of 0.000 ; thus, the sampling measure is adequate for further analysis.

\section{Scale reliability}

Cronbach's alphas were calculated for both construct and dimensions in the conceptual model $[59,60]$. Cronbach's alpha is the most widely used method of reliability assessment in Information Systems Research [61] and is based on the correlations among the indicators that comprise a measure, with higher correlations among the indicators associated with high alpha coefficients [62]. Cronbach's alpha values in Table 5 all exceed

Table 2 Descriptive statistics

\begin{tabular}{|c|c|c|c|c|c|c|c|c|c|}
\hline \multirow[t]{2}{*}{ Item } & \multirow{2}{*}{$\begin{array}{l}\mathrm{N} \\
\text { Statistic }\end{array}$} & \multirow{2}{*}{$\begin{array}{l}\text { Minimum } \\
\text { Statistic }\end{array}$} & \multirow{2}{*}{$\begin{array}{l}\text { Maximum } \\
\text { Statistic }\end{array}$} & \multirow{2}{*}{$\begin{array}{l}\text { Mean } \\
\text { Statistic }\end{array}$} & \multirow{2}{*}{$\begin{array}{l}\text { Standard deviation } \\
\text { Statistic }\end{array}$} & \multicolumn{2}{|c|}{ Skewness } & \multicolumn{2}{|l|}{ Kurtosis } \\
\hline & & & & & & Statistic & $\overline{\text { Std. error }}$ & Statistic & Std. error \\
\hline DNE1 & 213 & 1.0 & 7.0 & 4.150 & 2.004 & -.276 & .167 & -1.172 & .332 \\
\hline DNE2 & 213 & 1.0 & 7.0 & 3.798 & 2.040 & -.046 & .167 & -1.293 & .332 \\
\hline INE1 & 213 & 1.0 & 7.0 & 4.615 & 1.792 & -.600 & .167 & -.535 & .332 \\
\hline INE2 & 213 & 1.0 & 7.0 & 4.366 & 1.739 & -.495 & .167 & -.548 & .332 \\
\hline INE3 & 213 & 1.0 & 7.0 & 4.080 & 1.983 & -.156 & .167 & -1.169 & .332 \\
\hline INE4 & 213 & 1.0 & 7.0 & 4.601 & 1.852 & -.611 & .167 & -.569 & .332 \\
\hline SCRMA & 213 & 1.0 & 7.0 & 4.535 & 2.179 & -.325 & .167 & -1.274 & .332 \\
\hline
\end{tabular}

DNE1 direct network externality 1, DNE2 direct network externality 2, INE1 indirect network externality1, INE2 indirect network externality 2, INE3 indirect network externality 3, INE4 indirect network externality 4, SCRMA social CRM adoption 
Table 3 Correlations

\begin{tabular}{llllllll}
\hline Item & DNE1 & DNE2 & INE1 & INE2 & INE3 & INE4 & SCRMA \\
\hline DNE1 & 1 & & & & & & \\
DNE2 & $.664^{* *}$ & 1 & & & & & \\
INE1 & $.558^{* *}$ & $.628^{* *}$ & 1 & & & & \\
INE2 & $.520^{* *}$ & $.611^{* *}$ & $.875^{* *}$ & 1 & & \\
INE3 & $.393^{* *}$ & $.371^{* *}$ & $.434^{* *}$ & $.429^{* *}$ & 1 & $.534^{* *}$ & 1 \\
INE4 & $.513^{* *}$ & $.537^{* *}$ & $.704^{* *}$ & $.694^{* *}$ & $.409^{* *}$ & $.473^{* *}$ & 1 \\
SCRMA & $.438^{* *}$ & $.488^{* *}$ & $.528^{* *}$ & $.459^{* *}$ & .400 & & \\
\hline
\end{tabular}

${ }^{* *}$ refers to $p=0.05$

the value (0.70) generally considered adequate for assessing reliability in empirical research [63]. The scale items used in this research can thus be considered reliable. Additionally, the value of determinant of the reliability (i.e., 0.023) in this study is greater than 0.00001 , and thus, there is no multicollinearity problem.

\section{Content and construct validity}

This study and paper tests both content validity and construct validity. Cooper and Schindler [64] recommended two methods of determining content validity. The first method is through a careful definition of the concerned subject, the scaled items, and the scales to be used. The second method is utilizing a panel of experts to judge how well the instrument achieves its standard. In this paper, the operationalization of the constructs is drawn upon network externality and SCRM literature. The items used in this research are adopted from previous innovation and adoption studies. Moreover, a panel of experts from industry has preliminarily examined the instruments.

Construct validity demonstrated how well a test represented the underlying construct [64]. This study tested three types of tests, including unidimensionality, convergence validity, and discriminant validity tests, to assess construct validity.

There are two common methods for assessing the unidimensionality of a measure: exploratory factor analysis (EFA) and confirmatory factor analysis (CFA) [65]. The major difference between EFA and CFA is that, under EFA, the association between the scale items and latent variables are not pre-specified, while in CFA, the associations are specified [66]. This study uses EFA to test the unidimensionality. Table 6 represents the factor matrix showing that the two questions that load highly on factor 1 are all related to direct network externality (DNE), while the four questions that load highly on factor 2 are all associated with indirect network externality (INE).

Convergent validity concerns the degree to which multiple methods of measuring a variable provide the same results. Stand-alone indices (Stata 12) are used to test

Table $4 \mathrm{KMO}$ and Bartlett's test

\begin{tabular}{lll}
\hline KMO and Bartlett's test & & \\
\hline Kaiser-Meyer-Olkin measure of sampling adequacy & & .840 \\
Bartlett's test of sphericity & Approx. chi-square & 787.654 \\
& $d f$ & 15 \\
& Sig. & .000 \\
\hline
\end{tabular}


Table 5 Reliability

\begin{tabular}{|c|c|c|c|}
\hline Item & Variable & Reliability & Composite reliability \\
\hline DNE1 & DNE & .798 & .883 \\
\hline \multicolumn{4}{|l|}{ DNE2 } \\
\hline INE1 & INE & .859 & \\
\hline \multicolumn{4}{|l|}{ INE2 } \\
\hline \multicolumn{4}{|l|}{ INE3 } \\
\hline INE4 & & & \\
\hline
\end{tabular}

convergent validity. They are based on maximum likelihood estimation, which performs much better than indices derived from the generalized least squares approach [67]. Stand-alone indices include Tucker-Lewis (TLI), competitive fit index (CFI), root mean square error of approximation (RMSEA), $\chi^{2}$, and $\chi^{2} / d f$. Hu and Bentler [67] recommended a maximum cutoff value close to 0.06 for RMSEA. A minimum cutoff value close to 0.9 is suggested for TFI and CFI [68]. The $\chi^{2}$ value should be significant at the 0.05 level [65]. The recommended value of $\chi^{2} / d f$ is less than 3.0 [69].

Table 7 shows the summary of the CFA measures of the conceptual model. The RMSEA (0.05), $\chi^{2}$ (significant at a level of 0.01 ), and $\chi^{2} / d f(91.157 / 210=0.430$ ) values meet the requirements for good fit. Both TFI and CFI values also exceed the minimum cutoff value of 0.90 . The constructs and scale items used in this study thus meet the requirements for adequate validity.

\section{Results and discussion}

Table 8 reports analysis results from applying linear regression, which demonstrates strong support for the hypotheses. Table 8 presents two models: model 1 shows the results of the construct-level model, while model 2 shows the results of the dimensionlevel model. $R$ square value is a measure of how much of the variability in the outcome is accounted for by the predictors. For the first model, the $R$ square value is 0.341 , which means that network externality accounts for $34.1 \%$ of the variation in SCRM adoption. Similar results are rendered for model 2. The $F$ values for both models are 109.49 and 54.581, respectively, which are highly significant $(p<.001)$. These results support all the hypotheses.

More specifically, for model 1 , network externality (NTE), $\beta=0.584, t=10.464$, $p=0.000$, is a significant predictor of SCRM adoption in organizations. For model

Table 6 Factor matrix

\begin{tabular}{ll}
\hline Item & Factor \\
\hline DNE1 & 2 \\
DNE2 & .755 \\
INE1 & .797 \\
INE2 & .891 \\
INE3 & .877 \\
INE4 & .630 \\
\hline
\end{tabular}


Table 7 Fit indices

\begin{tabular}{|c|c|c|}
\hline Fit statistic & Value & Description \\
\hline \multicolumn{3}{|l|}{ Likelihood ratio } \\
\hline $\begin{array}{c}\text { chi2_ms( 0) p > } \\
\text { chi2 chi2_bs( 2) } p \\
>\text { chi2 }\end{array}$ & $\begin{array}{l}0.000 \\
91.157 \\
0.000\end{array}$ & Model vs. saturated baseline vs. saturated \\
\hline \multicolumn{3}{|l|}{ Population error } \\
\hline $\begin{array}{l}\text { RMSEA } \\
90 \% \text { Cl } \\
\text { Lower bound } \\
\text { Upper bound } \\
\text { p close }\end{array}$ & $\begin{array}{l}0.000 \\
0.000 \\
0.000 \\
1.000\end{array}$ & $\begin{array}{l}\text { Root-mean-square error of approximation } \\
\text { Probability RMSEA } \leq 0.05\end{array}$ \\
\hline \multicolumn{3}{|l|}{ Baseline comparison } \\
\hline $\mathrm{CFI}$ & 1.000 & Comparative fit index \\
\hline TLI & 1.000 & Tucker-Lewis index \\
\hline
\end{tabular}

2, direct network externality (DNE), $\beta=0.246, t=3.266, p=0.001$, and indirect network externality (INE), $\beta=0.390, t=5.170, p=0.000$, are significant predictors of SCRM adoption in organizations. This supports the acceptance of H1a and H1b, where higher levels of perceived direct and indirect network effects are positively associated with the intent to adopt SCRM in organizations.

Lastly, none of the control variables were significant. This supports the contention that the variable relationships established in this study are not significantly influenced by control factors of firm size, industry, and job tenure. This lends a greater degree of certainty to the findings.

The main purpose of this study was to examine the effects of network externalities on SCRM adoption in organizations. Research hypotheses formulated using network externality theory were tested using data collected from a questionnaire survey. The linear regression method was applied to test the hypotheses. The analysis results showed that both models were highly significant $(p<0.001)$. The models revealed that network externalities positively influence SCRM adoption. Moreover, perceived direct and indirect network effects were both shown to be positively associated with the intent to adopt SCRM in organizations.

This study represents part of an overall effort to systematically build a model of adoption behavior for SCRM technology and test it within the context of supply chain

Table 8 Results

\begin{tabular}{|c|c|c|c|c|c|}
\hline \multirow[t]{2}{*}{ Model } & \multicolumn{2}{|c|}{ Unstandardized coefficients } & \multirow{2}{*}{$\begin{array}{l}\text { Standardized coefficients } \\
\text { Beta }\end{array}$} & \multirow[t]{2}{*}{$t$} & \multirow[t]{2}{*}{ Sig. } \\
\hline & $B$ & Std. error & & & \\
\hline \multicolumn{6}{|c|}{ Model 1 (construct) } \\
\hline (Constant) & 1.094 & .350 & & 3.127 & .002 \\
\hline NTE & .820 & .078 & .584 & 10.464 & .000 \\
\hline \multicolumn{6}{|c|}{ Model 2 (dimension) } \\
\hline (Constant) & .946 & .371 & & 2.546 & .012 \\
\hline DNE & .146 & .045 & .246 & 3.266 & .001 \\
\hline INE & .551 & .106 & .390 & 5.175 & .000 \\
\hline \multicolumn{6}{|c|}{ Model 1: $R=.584 ; R$ square $=.341 ;$ adjusted $R$ square $=.337 ;$ std. error $=1.7701 ; F$ value $=109.490 ; p=.000$} \\
\hline \multicolumn{6}{|c|}{ Model $2: R=.585 ; R$ square $=.342 ;$ adjusted $R$ square $=.336 ;$ std. error $=1.7763 ; F$ value $=54.581 ; p=.000$} \\
\hline
\end{tabular}


management. The aim is to stimulate further research in this area where application of SCRM in organizations is in the infant stages. The results of this study have practical implications for both organizations and researchers in the field.

First, the results establish the role and value of network externalities in driving the adoption of SCRM and provide a mechanism for using network externalities theory to predict the adoption of SCRM innovations in a firm. Second, the results position network externalities as a significant piece of the adoption model for SCRM, the remainder of which can perhaps be filled by previously identified SCRM adoption models. Finally, the results provide organizations a practical framework for not just driving adoption of SCRM technologies, but also selecting which SCRM technologies will be most readily adopted, as a consequence of direct and indirect network externalities.

The results of this study suggest that practitioners must be mindful of the shift that is happening now in the use of big data in managing customer relationships. They must also examine the interorganizational effects to understand SCRM and be prepared to participate in it. Due to the very nature of being a part of a network, leaders in supply chain management in particular should seek to understand SCRM technology and consider playing a leadership role in the adoption of SCRM technology within their organizations.

When large, industry-leading firms in the supply chain start to adopt SCRM, the network effect they create will likely be strong [70]. Other firms in the supply chain will benefit from using this network effect to increase their own effectiveness in using SCRM to share and collaborate with customers.

On the other hand, when medium or smaller firms adopt SCRM technology before their key large accounts do, these firms will have the advantage of being the early adopters. In addition to potentially gaining the ability to tap into unprecedented market trend and customer feedback data, these firms, due to their lower organizational complexities, will have the opportunity to understand the technology and its adoption from both the intraorganizational and interorganizational perspectives.

The interorganizational and intraorganizational learning about SCRM adoption include the size of the SCRM user base which will impact ease of use, training availability, maintenance, and interoperability, as well as the general market and system reliability of SCRM. It also provides opportunities for these early adopters to become the leader in SCRM application in the industry and to be able to recruit high-caliber technical personnel in this area before the rest of the supply chain.

In addition, when other suppliers and customers jump on the bandwagon and start to adopt SCRM in reaction to accumulating direct and indirect network effects, these early adopting firms may want to seize the opportunity to share their adoption experience and work with these suppliers or customers more closely during their adoption process. This may help them gain further benefit for their business in the long run. The power of the so-called critical mass to aid in adoption through social interaction is a valuable aid to managers looking to make technological (and therefore institutional) change. This is supported by the strongly significant outcomes for both direct and indirect externalities.

For managers, it is important to note that these results rely on the perceptions of SCRM users or potential SCRM users, rather than on any objective values related to 
ease of use, system reliability, or authorizations. The implications of this fact are that managers may, to some extent, influence SCRM adoption by influencing the perceptions of the target adopters. The data suggest that successful efforts to train, obtain buy-in, and emphasize system usability and reliability may, in turn, influence perceptions of related network externalities and thereby drive SCRM adoption. As another example, direct network externalities, such as the status effects of having SCRM, may also be subject to managerial influence. Specifically, the more positively SCRM adopters perceive these characteristics of the system, the more likely it is that the firm will successfully deploy, diffuse, and adopt the SCRM system. Therefore, managers should focus attention of system selection that maximizes positive adoption characteristics related to direct and indirect externalities and then engage employees with training and information campaigns that support raising perceptions of those characteristics.

\section{Conclusions}

\section{Limitations and future research}

There are several limitations of the study. First, this study is based on a cross-sectional design where data were collected from different business types across various industries. However, the cross-sectional design has its limitations, as it does not eliminate all the external factors in gathering industry-specific information. Future research will strive to explore both individual categories of industries as well as a broader collection of industries within this research framework. In doing so, the sample size of the survey will need to be increased.

The second limitation is that the survey data (questionnaires) are based upon managers' perceptions. While this is a viable operational process for measuring various constructs, all questionnaire surveys are restricted by the knowledge and "good faith" of the respondents. Nevertheless, the validation and reliability analyses undertaken in this study provided some level of assurance of the instrument's ability to capture useful measures.

Third, and finally, as other literature in technology (particularly social technology) adoption suggests, network externalities alone might not be adequate to fully explain innovation adoption. The authors further hypothesize that network externalities may be have a combinatorial effect with other adoption theories (e.g., technology, organization, and environment (TOE) framework, task-technology fit model) that have been previously suggested in the literature. Future research will seek to explore these combinations and find more valuable SCRM adoption models thereby.

Acknowledgements

Not applicable.

Funding

Not applicable.

\section{Authors' contributions}

All authors participated in the development of the survey instrument. RC additionally helped conduct the survey and designed the experiment and data analysis. Dr. Cao also drafted the "Methods" and "Results" sections. VG additionally helped design the experiment, analyze the data, and contributed to the writing of the introduction and literature review. JD additionally helped interpret the experimental results; drafted the literature review, discussion, and conclusions; and managed the paper editing and final submission. JV additionally helped conduct the survey, interpret the results, and drafted the introduction. Dr. Vogt further contributed to the writing of the literature review and conclusions. All authors read and approved the final manuscript. 


\section{Competing interests}

The authors declare that they have no competing interests.

\section{Author details}

${ }^{1}$ The University of Houston Clear Lake, 2700 Bay Area Blvd, Houston, TX 77058, USA. ${ }^{2}$ The University of Houston Downtown, One Main Street, Houston, TX 77002, USA.

Received: 20 June 2017 Accepted: 29 November 2017

Published online: 20 December 2017

\section{References}

1. Mithas S, Krishnan MS, Fornell C (2005) Why do customer relationship management applications affect customer satisfaction? J Marketing 69:201-209

2. Askool S, Nakata K (2011) A conceptual model for acceptance of social CRM systems based on a scoping study. Al Soc 26:205-220

3. Yawised K, Marshall P, Stockdale R (2013) Social CRM: a review of the academic and practitioner literatures and research agendas. In: MCIS, pp 101-107

4. Hasani T, Bojei J, Dehghantanha A (2017) Investigating the antecedents to the adoption of SCRM technologies by start-up companies. Telemat Inform, 5(34), 655-675.

5. Shapiro C, \& Varian H (1999) Information Rules. Harvard Business School Press, Boston, MA.

6. Katz ML, Shapiro C (1986) Technology adoption in the presence of network externalities. J Polit Econ 94:822-841

7. Metcalfe RM (2007) It's all in your head: the latest supercomputer is way faster than the human brain. But guess which is smarter? Forbes 179:52

8. Chen IJ, Popovich K (2003) Understanding customer relationship management (CRM) people, process and technology. Bus Process Manag J 9:672-688

9. Goldenberg B (2000) What is CRM? What is an e-customer? Why you need them now. In: Proceedings of DCI CRM, Boston, MA, pp 27-29

10. Jackson DW (1994) Relationship selling: the personalization of relationship marketing. AMJ 2:45-54

11. Levine J (1993) Relationship marketing. In: Forbes, pp 232-234

12. Frederick FR, Thomas T (1996) The loyalty effect: the hidden force behind growth, profits, and lasting value. Harvard Business School Press, Boston, Massachusetts

13. Lehmkuhl T, Jung R (2013) Towards social CRM-scoping the concept and guiding research. In: 26th Bled eConference: elnnovations: challenges and impacts for individuals, organizations and society, Bled, Slovenia

14. Greenberg P (2009) Social CRM comes of age. In: White paper sponsored by Oracle

15. Greenberg P (2010) CRM customer relationship management, social CRM strategies, tools, and techniques for engaging your customers, at the speed of light. McGraw Hill Professional, New York

16. Trainor KJ (2012) Relating social media technologies to performance: a capabilities-based perspective. J Pers Selling Sales Manage 32:317-331

17. Heller Baird C, Parasnis G (2011) From social media to social CRM: reinventing the customer relationship. Strat Leadersh 39:27-34

18. Kietzmann JH, Hermkens K, Mccarthy IP et al (2011) Social media? Get serious! Understanding the functional building blocks of social media. Bus Horizons 54:241-251

19. Faase R, Helms R, Spruit M (2011) Web 2.0 in the CRM domain: defining social CRM. IJECRM 5:1-22

20. Chang W, Park JE, Chaiy S (2010) How does CRM technology transform into organizational performance? A mediating role of marketing capability. J Bus Res 63:849-855

21. Jayachandran S, Sharma S, Kaufman P et al (2005) The role of relational information processes and technology use in customer relationship management. JMarketing 69:177-192

22. Srinivasan R, Moorman C (2005) Strategic firm commitments and rewards for customer relationship management in online retailing. J Marketing 69:193-200

23. Acker O, Gröne F, Akkad F et al (2011) Social CRM: how companies can link into the social web of consumers. J Direct Data Digital Mkt Prac 13:3-10

24. Küpper T, Lehmkuhl T, Wittkuhn N et al (2015) Social CRM performance model: an empirical evaluation. In: 28th bled eConference:\# eWellBeing, pp 418-435

25. Sarner A, Thompson E, Drakos N et al. (2011) Magic quadrant for Social CRM. Gartner

26. Sigala M (2011) eCRM 2.0 applications and trends: the use and perceptions of Greek tourism firms of social networks and intelligence. Comput Human Behav. 27:655-661

27. Trainor KJ, Andzulis JM, Rapp A et al (2014) Social media technology usage and customer relationship performance: a capabilities-based examination of social CRM. J Bus Res 67:1201-1208

28. Verhoef PC, Reinartz WJ, Krafft M (2010) Customer engagement as a new perspective in customer management. J Serv Res 13:247-252

29. Woodcock N, Green A, Starkey M (2011) Social CRM as a business strategy. J Database Mark Cust Strategy Manag 18:50-64

30. Chau PY, Tam KY (1997) Factors affecting the adoption of open systems: an exploratory study. Mis Quart:1-24

31. Zhu K, Kraemer KL, Gurbaxani V et al (2006) Migration to open-standard interorganizational systems: network effects, switching costs, and path dependency. Mis Quart 30:515-539

32. Premkumar G, Ramamurthy K, Nilakanta S (1994) Implementation of electronic data interchange: an innovation diffusion perspective. J Manage Inform Syst 11:157-186

33. Goodhue DL (1995) Understanding user evaluations of information systems. Manag Sci 41:1827-1844

34. Katz ML, Shapiro C (1985) Network externalities, competition, and compatibility. Am Econ Rev 75:424-440

35. Goolsbee A, Klenow PJ (2002) Evidence on learning and network externalities in the diffusion of home computers. J Law Econ 45:317-343

36. Gowrisankaran G, Stavins J (2004) Network externalities and technology adoption: lessons from electronic payments. RJE 35 
37. Grzybowski L (2015) The role of network effects and consumer heterogeneity in the adoption of mobile phones: evidence from South Africa. Telecomm Policy 39:933-943

38. Lin K-Y, H-P L (2011) Why people use social networking sites: an empirical study integrating network externalities and motivation theory. Comput Human Behav 27:1152-1161

39. Chiu C-M, Cheng H-L, Huang H-Y et al (2013) Exploring individuals' subjective well-being and loyalty towards social network sites from the perspective of network externalities: the Facebook case. Int I Inform Manage 33:539-552

40. Scaglione M, Giovannetti E, Hamoudia M (2015) The diffusion of mobile social networking: exploring adoption externalities in four G7 countries. Int J Forecasting 31:1159-1170

41. Gu VC, Schniederjans MJ, Cao Q (2015) Diffusion of innovation: customer relationship management adoption in supply chain organizations. Int J Qual Innov 1:6

42. Rodriguez M, Trainor K (2016) A conceptual model of the drivers and outcomes of mobile CRM application adoption. J Res Interact Mark 10:67-84

43. Yawised K, Marshall P (2015) Social CRM: a review of the literature and the identification of new research directions. Int J Vircom \& SocNet 7:14-20

44. Wamba SF, Carter L (2016) Social media tools adoption and use by SMEs: an empirical study. In: Social media and networking: concepts, methodologies, tools, and applications. IGl global, pp 791-806

45. Amelina D, Hidayanto AN, Budi NFA et al (2016) Investigating critical factors of social CRM adoption using technology, organization, and environment (TOE) framework and analytical hierarchy process (AHP). In: Advanced Computer Science and Information Systems (ICACSIS), 2016 International Conference on. IEEE, pp 233-238

46. Russell DM, Hoag AM (2004) People and information technology in the supply chain: social and organizational influences on adoption. Int J Phys Distrib Logist Manag 34:102-122

47. Pai J-C, F-M T (2011) The acceptance and use of customer relationship management (CRM) systems: an empirical study of distribution service industry in Taiwan. Expert Syst Appl 38:579-584

48. Raman P, Wittmann CM, Rauseo NA (2006) Leveraging CRM for sales: the role of organizational capabilities in successful CRM implementation. J Pers Selling Sales Manage 26:39-53

49. Weitzel T, Beimborn D, König W (2006) A unified economic model of standard diffusion: the impact of standardization cost, network effects, and network topology. Mis Quart 30:489-514

50. Gurbaxani V (1990) Diffusion in computing networks: the case of BITNET. Commun ACM 33:65-75

51. Chwelos P, Benbasat I, Dexter AS (2001) Research report: empirical test of an EDI adoption model. Inf Syst Res 12:304-321

52. YA A, Kauffman RJ (2001) Should we wait? Network externalities, compatibility, and electronic billing adoption. J Manage Inform Syst 18:47-63

53. Riggins FJ, Kriebel CH, Mukhopadhyay T (1994) The growth of interorganizational systems in the presence of network externalities. Manag Sci 40:984-998

54. Lee D, Mendelson H (2007) Adoption of information technology under network effects. Inf Syst Res 18:395-413

55. Gallaugher JM, Wang Y-M (2002) Understanding network effects in software markets: evidence from web server pricing. Mis Quart:303-327

56. Kauffman RJ, Mcandrews J, Wang Y-M (2000) Opening the "black box" of network externalities in network adoption. Inf Syst Res 11:61-82

57. Parthasarathy M, Bhattacherjee A (1998) Understanding post-adoption behavior in the context of online services. Inf Syst Res 9:362-379

58. Song M, Parry ME, Kawakami T (2009) Incorporating network externalities into the technology acceptance model. J Prod Innovat Manag 26:291-307

59. Flynn BB, Sakakibara S, Schroeder RG et al (1990) Empirical research methods in operations management. J Oper Manag 9:250-284

60. Vickery SK, Droge C, Markland RE (1993) Production competence and business strategy: do they affect business performance? Decision Sci 24:435-456

61. Chau PY (1999) On the use of construct reliability in MIS research: a meta-analysis. Info \& Mngt 35:217-227

62. Pedhazur EJ, Schmelkin LP (1991) Measurement, design, and analysis: an integrated analysis. Psychology Press, Hillsdale, NJ

63. Nunnally J (1978) Psychometric methods. McGraw-Hill, New York, NY

64. Cooper D, Schindler P (1998) Business research methods. Irwin/McGraw-Hill, Burr Ridge, IL

65. Kline RB (1998) Principles and practice of structural equation modeling. Guilford Press, New York, NY

66. Kim J-O, Mueller CW (1978) Introduction to factor analysis: what it is and how to do it. Sage Publications, Beverly Hills, CA

67. Hu L-T, Bentler PM (1998) Fit indices in covariance structure modeling: sensitivity to underparameterized model misspecification. Psy Meth 3:424

68. Bollen KA (1989) A new incremental fit index for general structural equation models. Sociol Method Res 17:303-316

69. Bagozzi RP (1980) Causal models in marketing. Wiley, New York

70. Fabiani S, Schivardi F, Trento S (2005) ICT adoption in Italian manufacturing: firm-level evidence. Ind Corp Change 14:225-249 